\title{
Annonces / Announcements
}

\section{Canadian Society for Renaissance Studies Meeting}

The next meeting of the Canadian Society for Renaissance Studies will be held on May 31, June 1 and 2, 1993 at Carleton University, Ottawa, Canada. Papers related to the following topics are especially welcome: Language and style in Middle French; Cultural encounter: 1492 and after; The question of race in the early modern period; Images and perceptions of Henry IV; The Jesuits Relations: A Renaissance text; The Middle Ages in the Renaissance; The Council of Trent. For more information, please contact Prof. Don Beecher, Department of English, Carleton University, Ottawa, Ontario, Canada K1S 5B6.

\section{Congrès de la Société Canadienne d'Etudes de la Renaissance}

La Société Canadienne d'Etudes de la Renaissance tiendra son congrès annuel les 31 mai, $1^{\text {er }}$ et 2 juin 1993 à l'Université Carleton, Ottawa, Canada. Les sujets suivants seront abordés: Etudes de langue et de style en moyen français; La question de la race à la Renaissance; Les contacts culturels: 1492 et après; Images et perceptions d"Henri IV; Les Relations des Jésuites: un texte de la Renaissance; Le Moyen Age dans la Renaissance; Le Concile de Trente. Pour de plus amples renseignements, communiquer avec M. Don Beecher, Department of English, Carleton University, Ottawa, Ontario, Canada K1S 5B6.

\section{Women and Text in Pre-revolutionary France Conference}

A conference on Women and Text in Pre-revolutionary France will be held, May 7-9, 1993 at the University of Waterloo, Waterloo, Ontario, Canada N2L 3G1. For more information, please contact Prof. Hannah Fournier or Jean-Philippe Beaulieu, Department of French, University of Waterloo, Waterloo, Ontario, Canada N2L 3G1.

\section{Medieval and Renaissance Studies Conference}

Conference on Medieval and Renaissance Studies: Public Structures, shaping the World in the Middle Ages and the Renaissance. Barnard College, New York City, USA, December 5, 1992. For more information, please contact Prof. Catharine 
350 / Renaissance and Reformation

Randall Coats, Department of French, Barnard College, New York, New York 10027, USA.

\section{Moreana}

La revue trimestrielle Moreana consacrera un numéro spécial à l'Utopie de Thomas More. Les auteurs sont invités à proposer leur titre et un résumé avant le $1^{\text {er }}$ janvier 1993 à Elizabeth McCutcheon, Department of English, University of Hawaii, Honolulu, Hawaii 96822, USA.

\section{Correction}

Correction: In the last issue of Renaissance and Reformation (Vol. XV, No. 3), an error occurred in the article entitled "Politics of John Donne's Devotions Upon Emergent Occasions: or, New Questions on the New Historicism" by Mary Arshagouni (pp. 233-248). Note 25 on page 248 should have read "Ibid, pp. 171,8". Prof. Arshagouni informed us also that her correct name is now Mary Arshagouni Papazian. We apologize to the author for these omissions. 